\title{
IJBF USURY (RIBA) AND THE PLACE OF BANK INTEREST IN ISLAMIC BANKING AND FINANCE
}

\author{
M. Raquibuz Zaman \\ Ithaca College, United States of America
}

\begin{abstract}
This paper examines the concept of usury or Riba as was understood at the time of the Prophet of Islam and his contemporaries in Mecca and Medina, and what differing interpretations of the term developed in succeeding centuries in Muslim populated countries of the world. It gives a brief summary of the concept of usury in Judaism and Christianity and how this term is equivalent of Riba in Islam. It demonstrates that Riba and interest are not synonymous terms, and that what Islam forbids is usury and not interest. It asserts that, although some interests are usurious, the claim by the contemporary Islamic Banking and Financial institutions, IBFIs, that these institutions are "Islamic" because the term interest is not used in their transactions, is misleading at best. It ends with the proclamation that true IBFIs are not only feasible, but also are inevitable to serve the needs of the Muslims around the world.
\end{abstract}

Key words: Profit sharing, Usury, Interest, Prohibition of usury, Islamic banking

JEL Classification: G12, G21

\section{Introduction}

Islamic Banking and Financial Institutions, IBFI, have been in operation in some countries for around four decades, yet in most Muslim countries where Islamic as well as conventional banks operate, the IBFI are relatively very small, and command even smaller market share. It is not that the majority of the Muslim citizens are ambivalent about Islam, but they do not either believe in the Islamicity of the IBFI, or that these institutions do not serve their needs. There are good reasons for skepticism on both counts.

The basic impetus for the creation of the IBFI came from the belief of their modern proponents that all interest, irrespective of type and magnitude, are 
usurious (Riba, in Islamic lexicon). In order to avoid the term "interest rate" the IBFI resurrected some financial practices that existed at the time of the Prophet Mohammad and the early centuries of Islam. The Islamic jurists continue to approve practices that were evolved from the earlier institutions and instruments without a critical examination to determine whether or not they meet the Islamic precepts of justice and fair play - some say efficiency - and serve the needs of the public in a Muslim country.

The objective of this study is to show the real historical meaning of the term usury or Riba in Islam, and why Riba should be interpreted as usury and not ordinary interest rates. It examines how Riba has come to be identified with interest at modern times, and how some Muslim scholars has incorporated this limited or narrower interpretation in forming the IBFI. A second objective is to show that not only Islam but Judaism and Christianity also struggled with the concept of usury for centuries. Finally, the study briefly describes the operation of the contemporary "Islamic" banking and financial institutions and shows how these can be changed and restructured to operate on truly Islamic principles.

\section{The Concept of Riba (Usury) in Islam}

\subsection{Prohibition of Riba according to the Holy Quran:}

"O you who believe! Devour not usury, doubling and quadrupling (the sum lent). Observe your duty to God, that ye may be successful."(Chapter III, Verse $130)$.

"O you who believe! Observe your duty to God, and give up what remain (due to you) from usury, if you are (in truth) believers. And if you do not, then be warned of war (against you) from God and His messenger. And if you repent, then you have your principal. Wrong not, and you shall not be wronged."(Chapter II, Verses 278-279).

"Those who swallow usury cannot rise up save as he arise whom the devil has prostrated by (his) touch. That is because they say: Trade is just like usury; whereas God permits trading and forbids usury. He unto whom an admonition from his Lord comes, and (he) refrains (in obedience thereto), he shall keep (the profits of) that which is past, and his affair (henceforth) is with God. As for him who returns (to usury) - such are rightful owners of the Fire. They will abide therein."(Chapter II, Verse 275).

"God has blighted usury and made almsgiving fruitful. God loves not the impious and guilty."(Chapter II, Verse 276).

The Arabic word for usury is Riba (pronounced as Rēe'ba). According to the Holy Quran (Chapter 3, Verse 130, quoted above), Riba is defined as "doubling and quadrupling (the sum lent)." This is the only definition of Riba available from the Quran. All the other verses (all of which were quoted above) admonish the believers to refrain from usury and avoid God's punishment. Judaism and Christianity, also ask their followers to refrain from usurious transactions to avoid burning in hell fire (Homer 1997: 69-81). The classic commentators of Quran, such as, al-Tabari (d. 923 A.D.), Zamakhshari (d. 1144 
A.D.) and Ibn Kathir (d. 1373 A.D.) argued that the Quranic verse 3:130 on Riba essentially talks about Riba-al-Jahiliya (i.e., usury practiced in the pre-Islamic period in Arabia). Al-Tabari in his Jami (4:49) points out that Riba in the preIslamic period referred to doubling and redoubling of the principal amount lent in commodities over a period of time. At the due date, if the borrower failed to repay the amount borrowed, the loan was extended for another year but the borrower had to pay double the quantity originally lent. If, at the end of the second year, the borrower again failed to repay the loan, the loan was extended again for double the quantity of the second year to be repaid next year. Thus, in two years' time, the insolvent borrower would owe the original lender four times the quantity lent to him at the outset.

Al-Zamakhshari, in his al-Kashshaf (p. 234, date of publication unknown), presents a similar interpretation pointing out that even a small debt could consume all the wealth of a debtor because of repeated doubling of the unpaid loan. Ibn al-Arabi, (d. 1240 A.D.) in his Ahkam al-Quran (no date, V. 1: 241), also gives a similar interpretation of Riba, that is Riba al-Jahaliya. Prophet Muhammad in his farewell Hajj, clearly proclaimed that ". . Riba alJahiliya is null and void from this day and that Riba of Abbas bin Abdul-Muttalib has been waived." Ibn al-Arabi (Op. Cit.: 241) states that: "Riba was well known among the Arabs. A person would sell something on a deferred payment basis and upon maturity the creditor would ask: 'Will you pay (now) or add an amount to the bill'?" (See also, Zaman, M. R., and Movassaghi, H. 2002).

Those who equate Riba with interest seek support from al-Jassas (d. 981 A.D.), who claimed that pre-Islamic Arabia practiced a form of Riba where money was lent at a predetermined sum over the principal amount (Ahkam alQuran, V. 1: 465). However, there is no historical evidence to suggest that Riba al-Jahiliya also consisted of transactions that were similar to modern loans on interest (Suhail 1936, Tantawi 1989, Afzal 1996, et al.).

Thus, the basis for equating all forms of interest, whether they double or quadruple the principal or whether they are a small fraction of the principle, must be sought elsewhere. Let us look at the verified traditions or sayings (Hadith) of Prophet Muhammad, which are the second major source of Islamic (Shari'ah) jurisprudence.

\section{Riba in Hadith Literature and their Interpretation by the Muslim Jurists (Fuqaha)}

The traditions (i.e., Hadith) of Prophet Mohammad on Riba are essentially confined to Riba al-Fadal dealing with the borrowing or lending of commodities e.g., gold, silver, etc. but returned/exchanged at the same point in time. These "hand to hand" transactions do not make any sense - why would anyone borrow, i.e., exchange gold for gold or for silver, unless it is part of a barter transaction, which is perfectly legitimate form of trade under Islam. More about this later in the paper. 
The Sahih Al-Bukhari (1976, Volume III) cites a considerable number of

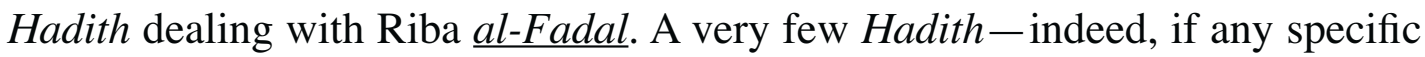
one - can be found in the verified collection of Hadith (1) on Riba al-Nasia, i.e., collection of fixed and predetermined percentages of return on the amount of money lent, popularly known as "interest." Then one wonders what is the basis for regarding all kinds of interest as usurious? Is it the meaning of the Arabic word Riba itself which lends to this type of assertion? The word Riba apparently means "an excess or addition - i.e., an addition over and above the principal sum that is lent" (M. M. Ali, no date, page 323, quoted from Lane's Arabic-English Lexicon). If the Muslim jurist are referring to interest as usury on the basis of this literal meaning of Riba, then naturally one wonders why God Almighty used the terms "doubling" and "quadrupling" (the sum lent) as usury in Chapter 3 Verse 130 (quoted above), and why there was no further clarification of this verse or by the Prophet. Some of the Muslim writers (see for example, Afzalur-Rahman, 1976, Volume III, pages 1-189) who claim interest is Riba, have no problems in explaining the verses of the Quran and the Hadith, as they simply translate the term Riba as interest and then assert it is forbidden (Ibid., Chapter 4). It appears as though they start with an axiom that interest is Riba and, as such, forbidden. There is no other basis.

It is instructive to note here that while the Quran refers to Riba in the context of loan (debt), the Hadith literature cites it in the context of sales, and there is no mention of loan (qard) or debt (dayan). One such Hadith that is often quoted, and is known by the epithet "six commodities Hadith" relates to the time around the Khyber Expedition - well before the prohibition on Riba was imposed by God's revelation (Afzal, Op. Cit., 3) - was as follows (it was narrated by Abu Sa'id al-Khudri on the authority of the prophet):

"Gold is to be paid for by gold, silver by silver, wheat by wheat, barley by barley, dates by dates, salt by salt, like by like, payment being made hand to hand. He who made an addition to it, or asked of an addition, in fact dealt in usury. The receiver and the giver are equally guilty." (Muslim, no date, V. III: 834).

This particular injunction said to have made by the Prophet to stop the cheating of the Muslims by the defeated hypocrites of Medina who were trying to get back the valuables they had to surrender as part of the Khyber Treaty. Muawiah, the fifth Caliph, a very learned man of his time, questioned the validity of this hadith and also calling such transactions Riba (Suhail1936).

It is important to note here that when one borrows one commodity to be returned later, it is no longer "hand to hand"-there is an elapsed time and, as such, it comes under the purview of Riba al-nasia, i.e., deferred payment. If we were to accept the "six commodities hadith" then all transactions that did not involve the use of money (i.e., barter trade) would be usurious. This is unacceptable from the view point of rational thinking as well as religious and moral principles. The Muslim jurists, depending on how transactions are worded, consider nasia transactions as installment payments at a higher price than the original (salam sale) or pre-determined mark up on the original price to be paid 
over time (murabaha transaction), and, therefore, permitted. Others contend that all nasia transactions to be usurious. Ironically, IBFI not only consider these transactions to be permissible, but make most of their profit from such practice! About 70 percent of assets in IBFI are Murabaha assets, while in the case of conventional banks, two-thirds of assets are murabaha (loan) contracts.

Two concepts, illa (efficient cause) and hikma (rationale) need to be considered. The Fukaha use illa to describe a transaction to be dealing with Riba. For example the Quranic verse lakum ru'usu amwalikum (i.e., "you shall be entitled to the return of your principal." 2: 279) is used for illa, ignoring the remainder of the verse, la tazlimuna wa-la tuzlamun (i.e., "you will do no wrong, and neither will you be wronged."), which provides the hikma. If the first part of the verse was taken literally, then the IBFI policy of profit/loss sharing cannot be accepted. The following excerpt from Afzal (1996) is quite instructive:

"In many case the 'Illa' approach appears superficial and devoid of moral considerations. For example, coins like 'fals' did not involve Riba in Maliki, and Shafi'i schools. Thus 100 'fals' (which were used as a unit of currency but were not made of gold or silver) could be exchanged for 200 either on the spot or on a deferred delivery basis. (Why today's fiat money could also be not counted in this category, is a good question to ask). Commodities which were countable like apples and eggs did not involve Riba, and hence could be exchanged less for more according to Hanafis. A piece of cloth could be exchanged for two pieces of the same quality and measure since it was neither measurable, or weighable, or gold or silver, or foodstuff."

Let us now go back to the issue of Riba and interest. The contention of this author is that the two most important sources of the Shariah (i.e., the Quran and the Hadith) do not provide us with clear guidance as to whether or not interest is Riba (i.e., usury). Some of the Fuqaha or Muslim jurists are of the opinion that interest is Riba and, as such, it is prohibited. This view can be acceptable if it is solely based on the argument that the word Riba has only one meaning, and that is "an addition over and above the principal sum lent." All other arguments against interest (i.e., rates of interest which are only fractions of the principal sum) such as provided by Muslim writers or scholars are, at best, superfluous and self-serving. If Riba means any addition over money lent out, then no one can loan out money to someone else or an organization to share in profits or losses. In other words, one cannot be an inactive participant in business or trade ventures and share profit because he/she cannot get back money which is in "addition to the sum lent." Just because one is ready to accept losses, does not entitle one to claim a part of the profit because he/she is a partner in capital. If Riba really meant "an addition to sum lent," then how did the traders during the life of the Prophet share their profits and losses with their aged and/or female partners who could not physically participate in the long journeys that such trades required?

Mudaraba or joint ownership does not necessarily mean that every single shareholder actively participates in the decision making process as well as the 
implementation of the decisions. If Islam permits Mudaraba then it is difficult to understand how Riba can mean, "an addition to the sum lent."

Once Riba is defined as "an addition to the sum lent," all arguments for joint enterprises, cooperative ventures (as not all members of the coops can participate in the decision making process or in implementation of those decisions), interest-free banking, and/or Islamic monetary policies become redundant and all these institutions become forbidden for the Muslims. The so-called interest-free banks that operate in some of the Muslim countries are really indirect participants in Riba, in its literal sense. The practice of payments of commissions to the depositors or charging of variable or fixed fees from the borrowers, or lending less than the contracted amount while recovering the full amount, cannot be anything less than Riba-i.e., "an addition to the sum lent". On the one hand, the IBFI claim interest is Riba and, as such, forbidden, while on the other, they are dealing in interest, but calling it profit/loss sharing.

The fukaha, it seems, have developed quite narrow interpretations of the term Riba to suit their own line of thinking. Some just substitute "interest" for the term Riba. Among them are Siddiqui 2006, 1987 and 1986; Chapra 1985; Naqvi 1993; Faridi 1991; Wohles-Scharf 1983; and Anwar 1987, who argue that IBFI cannot deal with interests. Whereas, Sanhuri 1954-1959; al-Saud 1985; Tantawi 1989; Salus 1991; Suhail 1936; Yousuf Ali 1946 (in his commentaries on Quran 2:275 and 2:324); Shah 1967; Rahman 1980; and Afzal 1996, make a clear distinction between Riba and interest.

\section{The concept of Usury in Judaism and Christianity}

It appears that Judaism allowed usury to be extracted from non-Jews only. Nelson (1969) quotes Deuteronomy Xxiii: 20, thus:

"From him, it says there, demand usury, whom you rightly desire to harm, against whom weapons are lawfully carried. Upon him usury is legally imposed. On him whom you cannot easily conquer in war, you can quickly take vengeance with the hundredth. From him exact usury whom it would not be a crime to kill. He fights without a weapon who demands usury: he who revenges himself upon an enemy, who is an interest collector from his foe, fights without a sword. Therefore, where there is the right of war, there also is the right of usury." (Nelson 1969, p. 4).

Nelson continues to quote St. Ambrose's interpretation of Deuteronomy, thus, "The Law forbids you under any circumstances to exact usury from your brother," who "is your sharer in nature, co -heir in grace, every people, which, first, is in Faith, then under the Roman Law." (Ibid., 4).

With the beginning of the Crusade in the Eleventh Century, the teaching of Ambrose gave the Christians an excuse to demand interest from Muslims, even though it was against the teaching of Jesus not to extract usury from anyone (Endnote 2). The Jews in Europe got the cue from this to charge usury from their Christian debtors (Ibid., 6). However, Christianity in Medieval and Renaissance Europe, in general, condemned usury, and started to make a distinction between 
usury and interest. Homer (1977) provides an excellent expose on the history of interest rates. He states that, "It was from exceptions to the canon law against usury that the medieval theory of interest slowly developed. Compensation for loans was not licit if it was a gain to the lender, but became licit if the compensation was not a net gain, but rather a reimbursement for loss or expense... It was often a compensation or penalty for delayed repayment of loan."(Homer 1977, p. 73). This is similar to the Riba transactions at the pre-Islamic Arabia, Ribaal-jahalia.

The Church doctrine on usury began to be modified around the sixteenth century when use of credit to finance wars and trade became prevalent. Theological controversies continued while the rise of Protestant ethics and capitalism made the use of interest in financial transactions quite common and acceptable to the public first in Germany and then after the Pope's edit in 1751, elsewhere thus laying the foundation of early banking. However, theologians continued to urge for regulation of interest rates - a rate of 5 to 6 percent interest on loans was not to be considered usurious (Ibid., 80). It was not until 1950 that Pope Pius XII declared that the banking system dealing with interest was permissible for the Catholics, because the bankers earned their livelihood honestly (Ibid., 81).

\section{Riba, Usury and Interest: A recapitulation}

From the short brief above on the position of Judaism and Christianity on usury and interest, it appears that Islam's position is more similar to that of the latter. Over the centuries both Judaism and Christianity changed their position, and came to accept that interest is not usury, provided it is regulated so that no party is unduly exploited. The texts by Nelson and Homer, referred above, are two good sources for detailed information about the evolution of the Jewish and Christian position on usury and interest.

Islam encourages Muslims to earn a living whether by working in agriculture, industry or trade, etc. As some of these professions require more capital than any one individual can muster, it allowed cooperatives and joint ventures among its followers. When a group of people directly or indirectly engages in joint ventures, it is not always possible for everyone to equally participate in all aspects of such ventures. Yet Islam allowed its followers to share in the profits and losses of these enterprises. If Riba meant "an addition to the sum lent," Islam could not permit such institutions. It is logical, therefore, to argue that the Muslim scholars should distinguish between fair loan (Qard-iHasna) and usurious loan (Qard-i-Saiya) and rearrange their entire thinking on capital, interest, banking and monetary policies.

It has become a fashion to condemn publicly all Western monetary institutions as anti-Islamic. Controlling interest rates through various interest rate ceilings and monetary policies, some of these countries run much superior, and socially equitable, financial institutions than some of the so-called Islamic states. The Western societies are not all unmindful of the consequences of usury, and some of them have laws prohibiting usury. Muslims may have much to learn 
from their experience. It would be proper to end this discourse on Riba and interest with the following Hadith:

"Narrated Aisha, (May God be pleased with her) the Prophet (PBUH) said, 'Why do some people impose conditions which are not present in the Allah's Laws? Whoever imposes such a condition as is not in Allah's Laws, then that condition is invalid even if he imposes one hundred conditions, for Allah's conditions are more binding and reliable."(Sahih al-Bukhari, Volume III, Chapter 69, Number 364).

\section{IBFI and their Modus Operandi}

The financial instruments used by the IBFI are numerous. According to Raphaeli (2006), the most frequently used ones are: "wadi'ah (safekeeping), mudharabah (profit sharing), murabahah (cost plus), ijarah (leasing), qardh al-hassan (benevolent loan), and musharakah (joint venture)".

Wadi'ah is a non-interest bearing demand deposit (checking account) similar to the ones offered by commercial banks around the globe (although since 1980 s, a small interest is paid on this account). It is also a non-interest bearing savings deposit account, but with a promise of giving hiba (gift) whenever the bank has "profits" to share! In practice though, IBFI claim to offer "hiba" which are a tad higher than the interests on savings account in conventional banks, to attract deposits. In practice, ordinary depositors get nothing and accept that as will of God.

Mudharabah (profit sharing) account is a form of time deposit that cannot be withdrawn before the contractual time is elapsed. The bank as the intermediary (mudharib) takes no risk when it lends money to the borrowers. The borrowers sign contracts that specify the principal amount borrowed and how much would be paid back, all predetermined. Since usually the "cost" of the loan is collected when the loan is given, i.e., the amount of the loan minus the "cost" is advanced, usually such loans are more expensive to the borrower than the ordinary commercial loans offered by conventional banks! If the borrower defaults on the loan, the loss is borne by the depositors to the bank. If the loan is repaid early, the borrower does not receive any part of the "cost" that the bank collected at the origination of the loan!

Murabaha (cost plus) transactions, a very profitable business for IBFI is no different in character than that of a finance company. The IBFI buys the merchandise, adds an amount for "profit" and sells it to the buyer, to be paid back in equal installments. Even if the borrower would attempt to pay back the loan ahead of time, the payments are not reduced. For all practical purposes, murabaha loans have implicit rate of fixed interest rates that are higher than on installment loans from a conventional financial institutions.

Ijarah (leasing) or ijarah waqtina (lease and purchase), is another way of enriching the IBFI at the cost of the borrower. The lessee cannot refinance or change the contract in view of changes in the market conditions. Any break in the contract goes in favor of the IBFI. Thus, the lessee can lose the equity in the 
property after paying payments for a number of years, if for some reason $\mathrm{s} / \mathrm{he}$ can no longer honor the contract!

Qardh al-hassan (goodwill loan) is given in good faith - the borrower is obliged to pay back the amount lent only, without any obligation to pay anything extra. It is quite obvious that not many loans would be given by a financial institution that is open for business of making money.

Musharakah (joint venture) in which an IBFI and clients jointly finance a venture by issuing 'participation certificates' that can be bought and sold in the market. This type of joint venture is commonly known as sukuk, and the 'participation certificates' are traded like bond. Apparently, the market for sukuk mushroomed to around $\$ 41$ billion (Raphaeli 2006) fueled by Middle Eastern oil money that is being invested in building booms and other infrastructure. It is not clear how returns on such instruments are determined but, the returns are predetermined nonetheless (Siddiqi 2006). If the past is any indication, it would be based on returns from similar instruments issued by "non-Islamic" entities and would simply be labeled as profit sharing. It would be interesting to watch what happens when an IBFI fails to meet its obligations on sukuk to the investing public.

The IBFI, at this period of bounties from oil exporting countries, seem to be doing financially alright. Hardly a day goes by when Islamic banking does not make into the pages of financial papers, e.g., The Financial Times, The Wall Street Journal, and The Economist (see for example, Prystav 2006, Diwany 2006, Tett, and Johnson 2006, Tett 2006, The Economist 2006, Davies 2006, Lane 2006, Saigol and Tett 2006, Bokhari 2006, and others shown in the Reference page).

\section{Assessing the Operations of the IBFI}

The brief review of the financial instruments above lends to an obvious question, in what ways do the so-called Islamic Banks and financial institutions qualify to be called Islamic? Apart from the claims that the IBFI follow Islamic "principles", there is no difference in their operations than the conventional financial institutions, CFI, except for the fact that the IBFI's principal thrust is towards maximizing their own coffers at the cost of depositors and the borrowers.

It can be demonstrated that the IBFI use religious slogans to misrepresent the common people that these are functioning to promote welfare of the believers. In reality, most of their loans cost lot more than what the conventional banks charge. While the CFI are subject to regulations and are accountable for their actions, the IBFI are probably more prone to corruption and mismanagement, all they need is a review from their shari'ah council (in cases where the NBFI are outside the supervision of central banks), that the transactions do not involve dealing with interest rates. The IBFI frequently place their customers' deposits into short term instruments of conventional banks abroad to earn interests so that they can present their own depositors shares of their interest earnings as "profits" and/or, advance hiba (gift) to them! 
In reality the IBFI are deposit-taking finance companies if outside the central bank purview. Here in lies their attractiveness to the major financial institutions of the developed West. It is not that the Citibank or HSBC suddenly developed fervor for "Islamic" banks and financial institutions. Where else they can find easy way of making money without any risk or responsibility to their clients, and without being subject to regulations. After all, the IBFI have been using their facilities to earn short term income (read, 'interest') and delve into futures, options, and other speculative transactions!

The IBFI, as institutions, seem to attract a fraction of the business of financial transactions in countries where CFI are allowed to operate. The total assets of all IBFI are miniscule (see the 2005-2006 Annual Report of the Islamic Development Bank) compared to the CFI in the Muslim countries, and compared to some of the regional banks' assets in the US. It will not take long for the Muslims to figure out that the sukuk transactions are nothing more than institutional bonds, but with mismatched risk-return relationship. It appears that no matter how the transactions are structured by the IBFI, as long as these are made into "contract" documents, these are termed as Islamic (Siddiqi 2006).

\section{Streamlining the IBFI}

The IBFI should be reorganized into three distinct operational units. One unit should deal strictly with commercial and consumer banking, and the second one with investment banking, and the third one with commercial financing. The sources and the uses of funds of these institutions should be clearly delineated to avoid misuse of funds and public trust.

Commercial banking: The sources of the fund are depositors' money and the equity financed by the bank shareholders, the share of the latter as directed by national and international standards for commercial banks. The depositors should earn flexible rates of return based on the overall costs of and returns for the bank during a quarter, or such time by which the bank can estimate its net returns. All deposits - ordinary savings accounts, or time deposits - should earn flexible rates, subject only to some adjustments for risks. Similarly, Certificates of Deposits, CDs, should also earn flexible returns, unlike in modern commercial banks.

In the past some modern banks have run into heavy disintermediation during rapid changes in the interest rates, and in some cases, went bankrupt when long term fixed loans at low rates could no longer be financed through costly deposits. The Islamic principles of justice and fair play require that no party should take advantage of the other. Only flexible rates of interest/return can assure that.

Insurance is an integral part of an Islamic economic system. Depositors' money, up to a certain limit, must be insured by some national system of insurance in a manner similar to the Federal Deposit Insurance Company of the US, or elsewhere. The depositors need to have some assurance that their funds would not be completely lost in case the bank faces serious economic problems. This is also compatible with Islamic injunction of safeguarding the principal. 
The uses of funds should be limited to commercial and consumer loans, e.g., accounts receivable financing, inventory financing, line of credit, installment loans for short and medium terms, and mortgage financing. All loans should also be on flexible cost basis, i.e., the rates charged for these loans must be adjusted periodically as suggested above, based on returns to banks as calculated say every three months. The FDI inflows from foreign commercial banks would increase with such a system since they will no longer be tied with fixed rate commitments. The business community and the consumers in the Muslim countries will prefer the new system to what exist in their communities now.

Investment Banking: The principal source of funds for this institution should come from the shareholders' equity. This can be supplemented by borrowing through the money market. Such a bank should not be allowed to use depositors' money. Its earnings will be fee based for intermediation services, and flexible returns from its investments. The activities of the investment bank should also be clearly monitored to avoid questionable practices and transactions. The role the investment bankers played in the Enron disaster in the US needs to be averted.

Commercial Financing: At present the IBFI are essentially finance companies. Their practices are contrary to what they are supposedly trying to avoid. The Murabaha transactions are fixed interest-bearing instrument in reality. No matter how quickly one pays back the loan, one has to pay the full extent of the so-called 'mark up', making them usurious (two-fold three fold increases in repayments). This and the instrument of ijarah Muntatahia Bittamleek should all be modified and standardized, removing the need for Shari,ah councils, and be based on flexible rates only.

While the recent trend in the world of banking and finance is mergers and consolidation of institutions and functions, the idea of proposing a break up of IBFI into three separate functional areas may appear to be far fetched. Yet, this possibly is a very sound way to learn the ropes of running a flexible rate based banking and financial system. From the practice of determining, more or less arbitrarily, the 'profit' or 'mark up' rate, the new institutions will have to institute a system of accounting to monitor very closely costs of and returns from operations so that they can set competitive rates for their customers. This will be a very difficult task, but must be undertaken in order to ensure that all parties are treated equitably.

It appears that the IBFI have hitherto faced very little supervision and scrutiny from the banking authorities of the countries where they operate. It was this lack of centralized supervision that led to the massive failure of the first NBFI in Egypt just few years after its founding in 1963. This needs to be remedied. Not only these should be brought under the supervision of the monetary authorities, especially the central banks, but also be subjected to regular examinations by the regulatory authorities, results of which should be made available to the public. The IBFI disclose very little information to the public, and this keeps the depositors, the borrowers, and the investors in the dark about their financial health. This calls for improved governance standards 
and compliance monitoring. The restructured IBFI must fulfill their fiduciary responsibilities wholeheartedly.

At present the IBFI lacks uniform standards and policies within and across national boundaries. There are attempts to bring in common accounting and financial practices by the Bharain-based accounting institute and Malaysia-based IFSB. These need to be aggressively instituted, subject to the overall banking and finance policies of individual states. There will not be any meaningful role for the ever-present Shari,ah councils in the reorganized IBFI, and these should be disbanded in due course of time with improved supervision structures. Banking and financial operations should be left on the shoulders of those who are well trained and well versed in the management of financial services and instruments.

\section{Conclusion}

It is important to realize that banking and financial institutions are engaged in a trade (tijara) that deals with the management of money and financial securities and services, and they do not operate like "money lenders" or "loan sharks." The depositors place their deposits either for a short or a longer period, seeking some returns to offset the loss of purchasing power if kept 'under the mattress', or to augment their future income, while the borrowers borrow to meet the needs for funds for business and/or consumption that are vital to them and are willing to pay a reasonable fee for the service. It should be borne in mind that banking/ financial institutions are only intermediaries and should act accordingly, and that the bank officials must be held accountable for their actions and should be held responsible for willful negligence.

Author statement: This is an invited contribution to the sixth volume of the Journal. It is contributed by a notable scholar, Raquibuz Zaman. Dr Zaman is the Charles A. Dana Professor of Finance \& International Business and Chair of the Department of Finance and International Business, Ithaca College, New York. His scholarly publications may be accessed in www.ithaca.edu/faculty/ zaman. E-mail: zaman@ithaca.edu. This paper was reviewed anonymously, and accepted after that as representing a point of view consistent with the ongoing historical debate on usury and interest.

\section{End Notes}

1. This author checked Sahih Al-Burkhari, Sahi Muslim, Mishkat al-Masabih, and A Manual of_Hadith (see References at the end of the paper) for various Hadith related to usury, debts, and general business transactions.

2. Apparently Jesus objected to Deuteronomy's position about extracting usury from enemies. In Luke vi: 35 : 
"But love ye your enemies, and do good, and lend, hoping for nothing again; and your reward shall be great, and ye shall be the children of the Highest: for He is kind unto the unthankful and to the evil." Nelson 1964, p.8).

\section{References}

Afzal, O. (1996) "Riba: Usury or Interest or Both", a Conference paper for the Islamic Chamber of Commerce and Industry (ICCI), San Jose, California, November, 7-9.

Afzal-ur-Rahman, (1976). Economic Doctrines of Islam, Vol. III, Lahore, Pakistan: Islamic Publications, Ltd.

Ahmad, Khurshid (editor), (1980). Studies in Islamic Economics, , Jeddah, Saudi Arabia: International Centre for Research in Islamic Economics, King Abdulaziz University, and the Islamic Foundation: United Kingdom

Ali, Maulana M., A Manual of Hadith, (no date of publication). Lahore, Pakistan: The Ahmadiyya Anjuman Ishaat Islam.

Al-Jassas, A.R. (no date), Ahkam al-Quran, V. 1, Istanbul, Turkey: 1916.

al-Saud, A.M. (1985), "Bain al-Faida wa al-Riba," Al-Shuruq al-Islami, April,1820.

al-Tabari, A.J.M. (no date), Jami' al-bayan 'an ta'wil ay al-Quran, English translation of the abridged version by Cooper, J., New York: Oxford University Press 1987.

al-Zamakhshari, M.I.U (no date), al-Kashshaf 'an Haqa'iq al-tanzil wa-'uyun al-aqawil fi wujuh al-ta'wil.

Ali, A.Y. (1946), the Holy Qur'an: Text, Translation and Commentary, Washington, D.C.: The American International Printing Company (no printing date).

Anwar, M.(1987), Modelling Interest-Free Economy: AStudy in Macroeconomics and Development, Herndon, Virginia: The International Institute of Islamic Thought.

Bokhari, F. (2006), "Oil Wealth Paves Way for Islamic MBA," The Financial Times, Monday, December 18: 10.

Bokhari, F., and Oakley, D. (2006), "Islamic Finance Gets Ready to Spread," The Financial Times, November 24: 29.

Bokhari, F. and Felsted, A. (2007), "Insurance: Takaful Cover Worth Billions Set to Take Off," The Financial Times, January 18: 17.

Chapra, M.U. (1985), Towards a Just Monetary System, London: The Islamic Foundation.

Croft, J. (2007), "Retail Products: World's Banks Respond to Growing Muslim Demand," The Financial Times, January 18: 17.

Diwany, T.E., (2006), "How the Banks are Subverting Islam's Ban on Usury," The Financial Times, July 14: 11.

Economist, The, (2006), "Islamic Finance: Calling the Faithful," The Economist, December $9^{\text {th }}, 77$. 
Faridi, F.R. (1991), Essays in Islamic Economic Analysis, edited volume, New Delhi: Genuine Publications (P) Ltd.

Homer, S. (1977) A History of Interest Rates (Second Edition), New Brunswick, New Jersey: Rutgers University Press.

Ibn al-'Arabi (no date), Ahkam al-Quran, Beirut: Dar-al-ikzat al-'Arabia, 1968, V. 1:24.

Islamic Development Bank (2006), Annual Report 2005-2006, Jeddah, Saudi Arabia, November 1.

Johnson, S. (2006), "How to Hedge and Abide by Sharia," The Financial Times, August 16, 14.

Khalaf, R., Tett, G., and Oakley, D. (2007), "Investment Routes: Eastern Promise Turns to Western Delight," The Financial Times, January 18: 17.

Lane, K. (2006), "Islamic- Bond Market Becomes Global by attracting NonMuslim Borrowers," The Wall Street Journal, November 16, C1 and C6.

Mackintosh, J. (2007), "Hedge Funds: Sharia-compliant Funds Aim to Test the Islamic Appetite," The Financial Times, January 18: 17.

Muslim, I. (1990) Sahih Muslim (Volume III), translated into English by Siddiqi, A.H., Lahore, Pakistan: Sh. Muhammad Ashraf.

Naqvi, S.R. (1993), History of Banking and Islamic Laws, Karachi, Pakistan: Hayat Academy.

Nelson, B. (1969), The Idea of Usury From Tribal Brotherhood to Universal Otherhood, (Second Edition, Enlarged), Chicago: The University of Chicago Press.

Oakley, D. (2007), "Pioneer Islamic-compliant Tracker Launched," The Financial Times,” January 9: 31.

Oakley, D. (2007), "Sukuk: Shock Fades as Deals Break Records,” The Financial Times, January 18: 17.

Prystay, C. (2006), "Mqalaysia Seeks Role as Global Player After Nurturing Islamic Bond Market," The Wall Street Journal, August 9, C1 and C4.

Raphaeli, N.(2006), "Islamic Banking-A Fast-Growing Industry," Inquiry and Analysis Series-No. 297, The Middle East Media Research Institute, September 29.

Rahman, F. (1980), Major Themes of the Quran, Chicago: Bibliotheca Islamica.

Sahih Al-Bukhari, Vol. III, (1967). Translated by Dr. Muhammad Muhsin Khan, , Ankara, Turkey: Hilal Yayinlari.

Sahih Muslim, Vol, III, (1976). Translated by Abdul Hamid Siddiqi, Lahore, Pakistan: Sh. Muhammad Ashraf.

Saigol, L. and Tett, G. (2006), "Investors Tap into Wave of Islamic Bonds," The Financial Times, September 18: 17.

Saleem, M. (2007), "Islamic Finance has Much to Learn from the West," The Financial Times, January 19, 13.

Salus, A.A. (1991), al-Rad 'ala Kitab Mufti Misr, Cairo: Dar al-Manar alHadithah. 
Sanhuri, A. (1954-1959), Masadir al-Haq $f i$ al-Fiqh al-Islami, 6 parts in 2 volumes (no other information available).

Siddiqui, M. N. (1976). Banking without Interest ( $2^{\text {nd }}$ Edition), Lahore, Pakistan: Islamic Publication, Ltd

Siddiqui, M. N. (1978). Some Aspects of the Islamic Economy ( $2{ }^{\text {nd }}$ Edition $)$, Lahore, Pakistan: Islamic Publications, Ltd.

Siddiqui, M. N. (1972). The Economic Enterprise in Islam, Lahore, Pakistan: Islamic Publications, Ltd.

Siddiqui, M.N. (1986), Model of an Islamic Bank, Chicago: Kazi Publications.

Siddiqi, M. N. (2006). "Islamic Banking and Finance in Theory and Practice: A Survey of State of the Art," Islamic Economic Studies, 13 (2): 1-48.

Suhail, I. (1936), Haqiqat al-Riba (no other information available).

Tantawi, M.S., et. al. (1989), Arbah al-bunuk baina al-Halal wa al-Haram, Cairo: Dar al-Ma'arif.

Tett, G. (2006), "Secondary Trading in Islamic Bonds Promisse Earthly Riches," The Financial Times, July 14: 20.

Tett, G. (2006), "Shariah-cmpliant Finance: Banks Create Muslim 'Windows' as Islamic banking Expands its Niche," The Financial Times, June 2, 6.

Tett, G. (2006), "London Gains Greater Role in Expanding Sharia Market," The Financial Times, June 2: 6.

Timewell, S. (1998) “A Market in the Making," The Banker, February 1998, London

Wohlers-Scharf, T. (1983), Arab and Islamic Banks: New Business Partners for Developing Countries, Paris: OECD Development Centre Studies.

Zaman, M.R., and Movassaghi, H.(2002), "Interest-free Islamic Banking: Ideals and Reality," in Ghosh, D. and Ariff, M. edited Regional Financial Markets: Issues and Strategies, Westport, Connecticut: Praeger Publishers, Chapter 14.

Zaman, M.R., and Movassaghi, H., (2001), "Islamic Banking: A Performance Analysis," Journal of Global Business, Vol. 12 (No. 22): 31-38. 